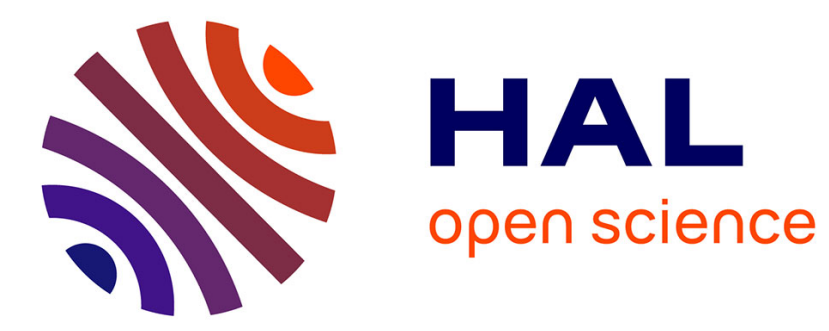

\title{
Resistance to Technological Innovation in Elite Sport Patrick Trabal
}

\section{To cite this version:}

Patrick Trabal. Resistance to Technological Innovation in Elite Sport. International Review for the Sociology of Sport, 2008, 43 (3), pp.313-330. 10.1177/1012690208098255 . hal-01471540

\section{HAL Id: hal-01471540 https://hal.parisnanterre.fr/hal-01471540}

Submitted on 18 Dec 2020

HAL is a multi-disciplinary open access archive for the deposit and dissemination of scientific research documents, whether they are published or not. The documents may come from teaching and research institutions in France or abroad, or from public or private research centers.
L'archive ouverte pluridisciplinaire HAL, est destinée au dépôt et à la diffusion de documents scientifiques de niveau recherche, publiés ou non, émanant des établissements d'enseignement et de recherche français ou étrangers, des laboratoires publics ou privés. 


\title{
RESISTANCE TO TECHNOLOGICAL INNOVATION IN ELITE SPORT
}

\author{
Patrick Trabal \\ Paris X-Nanterre University and Higher School of Social Sciences \\ (EHESS), Paris, France
}

\begin{abstract}
In 1998, the French Canoe and Kayak Federation embarked on the creation of a new kayak. However, there was concern it would not succeed in its venture due to 'social resistance'. This article aims therefore to reveal the social characteristics of those showing opposition to technological innovation, as well as those who are calling for it, and to determine the reasons behind reticence. A questionnaire was handed out to elite athletes, and interviews conducted with national coaches. The results show that, contrary to preliminary hypotheses, all athletes (including those of flat water racing) generally view such a project in a favourable light. The coaches express different types of 'resistance' - a term which should be used with caution, as it suggests legitimacy and faith in progress - which have less to do with the social position of the actors than with criticism of past and present policies of the Federation.
\end{abstract}

Key words $\bullet$ kayak $\bullet$ pragmatic $\bullet$ resistance $\bullet$ technological innovation

\section{Introduction}

Sport and science share the same ideal: to continually transcend the limits of the human being. This association between the Coubertin credo 'Citius, Altius, Fortius' and the aim of the technological sciences has been widely analysed in particular by Guttmann, for whom the development of modern sport is directly linked to that of science and technology (Guttmann, 1978). In these conditions, it could be construed that the introduction of technological innovations into elite sport would occur without a problem. However, this is far from the truth. The dialogue between the sporting world (athletes, trainers, technical staff) and that of research scientists into performance is a difficult one. First, there is the issue of an innovation being validated by international federations renown for their conservatism, which leads them to endorse legislation banning any innovation likely to change even slightly their respective sport. The range of constraints that are imposed on the International Federation of Rowing Organizations, the International Swimming Federation and the International Cycling Union in order to legislate activity following the respective introductions of movable handles (roller-skiff), immersion in backstroke, and bikes like that of Graeme Obree, have 
begun to be studied (Duret and Trabal, 2001). Second, adoption of the innovations by the athletes themselves is not achieved without tension. This can be accounted for by the athletes' focus on results and therefore their tendency towards a pragmatism based on empirics, as well as communication difficulties between athletes and scientists, the latter concerned entirely with validating hypotheses, statements or material only after a theoretical circumlocution which is highly incomprehensible in its content as much as its pertinence to those 'out there in the field'. But is this opposition sufficient in elucidating the way innovations are distributed in elite sport?

These questions can be studied by analysing the social conditions linked to the distribution of products susceptible to improve performance even before these products are validated by scientists. The success of the 'nasal breath-right device' is an interesting case in point: only after a large advertising campaign did scientists, wanting to ascertain its efficiency, prove it was questionable (Villiger, 1996). We can also attempt to approach the issue by following, within the sporting world, the path of an innovation as it seeks wide adoption. The latter course has been chosen for this study.

The background instigating the research presented here is to be found in the above questions as well as in a discussion with a member of the National Canoe and Kayak Federation, during which was broached a plan to create a new boat designed for flat water races, a single-seater kayak (K1). A new design is said to guarantee better stability and therefore offer a certain advantage to the athlete. Of course, the gains are minimal, but the smallest of differences can prove to be decisive in a close competition. However, attempts at a canoe and then a twoseater kayak which proved in vain have made the Federation member ask the following question: will the boat be used this time around?

This question was interpreted by members of the Federation in light of reflection on social resistance to the introduction of an innovation. In an interview in December 1996, a technical staff member shared some of his concerns with us, including the desire to 'move things along' and to 'gather together top athletes around this project'. This initial testimony highlights two difficulties in the Federation. In the first place, these words seem to indicate an inclination towards a relative opposition to progress (otherwise there would be no need to 'move things along') at least as far as the organization of flat water races are concerned. Second, his mention of top athletes (TA) seems to designate them as part of the 'opposition'. Just like the concern shown by the innovator in our first meeting, these two pieces of evidence suggest that the story of the K1's development is a turbulent one.

In this interview, we retrace the story from the years 1991-2, which marked, according to our witness, a turnaround, a change. His narration of the history up to this date designates the 'opposition', of which the athletes constituted the front line. 'Resistance': the word has been unleashed. 'They are quite happy to go faster, but as long as we don't speak to them about research or anything new. In a nutshell, they are ready to agree to the higher performance as long as not too many things are challenged.' Similar comments were used in reference to the trainers. Policy boiled down to using 'what works elsewhere', which means 'always being one Olympiad too late. The world champion's boat is taken and decreed the best 
boat.' The interview ends with two decisive pieces of information. First, it is emphasized that since 1992, 'attitudes are changing'. Athletes and coaches are apparently showing less 'resistance'. Second, in this world considered hostile to innovation, exceptions can but be noted. 'Those who come from wild waters' are said, however, to be promoters of innovation and change, unlike the 'flatties' (flat water racers). Populations developing within the field of 'descent' and 'slalom' are qualified as 'very receptive' to new projects and, according to our witness, it is expected that, in the course of our study, we be received with quite some enthusiasm by young people. Since, in actual fact, our work consists of 'identifying and understanding how social resistance to technological innovation is divided up and on what it is based', we had to meet with the whole spectrum of actors.

\section{The Question and Several Approaches}

Understanding resistance to technological innovation in the canoe-kayak field brings into play readings based on several different approaches. When dealing with the profile of sportsmen and women of canoe-kayak, problems entailing distribution of innovations and conflicts therefore created, and the history of instrumentation in sport, the social sciences have approached these questions within many different traditions. We will endeavour to explain these in order to determine the theoretical issues of the problems and to draw up our hypotheses.

There are few sociological studies on canoe-kayak. In fact, the only study which focuses on the conceptions of athletes is that of Lapierre (1981) to which our federal correspondents refer. The theoretical model which inspired this study is that of Bourdieu, which was applied to the sports field by sociologists like Pociello (1983, 1999; Pociello et al. 1981). The main aim is to distinguish the social agents and to show the relationship between their tastes (or distastes) and their social positions. This work is therefore based on the idea that 'the agents susceptible to choosing a sport and to committing themselves to it present within themselves cultural characteristics predetermining their choices' (Defrance, 1995). The sporting arena therefore exemplifies the link between the athletes' choices and the distribution of their social capital. Within one sport, the type of commitment would itself be subject to the athlete's social background. Like the work by Pociello on rugby (1983), that of Lapierre (1981) on canoe-kayak belongs to this school of thought. The different social groups perfectly overlap, according to this author, with the difference between wild water and flat water racing. On one hand, sportsmen belonging to a privileged social-cultural background, will choose a 'gliding' culture demanding analysis and mastery of the natural elements in order to surf with the wave and in which adaptation to a continually changing situation is a priority when choosing the right gesture to be carried out, and finally in which change, research into the latest equipment to save on physical exertion, and fast processing of information to succeed will be regarded favourably. On the other hand, sportsmen whose social capital is lower, will prosper in flat water racing, a discipline which places a high priority on long and continuous muscular exertion, in races where the exterior conditions remain stable (demarcation of the space with buoys removes orientation concerns or 
'reading the river'), demanding as essential competencies regular effort, and the capacity to uphold and use one's energy in a planned fashion. As a result, we can formulate an hypothesis, since the research in question suggests isomorphism between positions occupied by agents in the social space (resulting in particular from their scholastic and cultural capital) and their tastes in sport (as determined here in a preference for flat water racing, descent or slalom): the individuals progressing in wild waters, particularly the slalom racers, would be among the promoters of the new kayak and those practising wild water racing would remain in the background of this project. The explanation model follows on naturally from the theory of the distinction: the low capital of the agents progressing in line racing, measured as much in its volume as in its structure (low scholastic capital), their choice of a sport which necessitates a repetitive movement and a high level of physical exertion would lead them to consider technological innovation (which moreover they do not understand well) as a disruption, much akin to a diversion in the Pascal sense, the essence of their sport being summed up as follows: effort, work over a duration, self-sacrifice. We shall test this hypothesis by trying to examine how sportsmen from different specialities deal with technologies.

To do so, we have to clarify the ways used to put technological innovations into perspective. Sociological works concerning new technologies and their diffusion originate in different traditions. In order to pinpoint the principal schools of thought, we will distinguish between anthropological conceptions, theses of the Frankfort school, those from defenders of a 'technical system' and finally the work developed out of the sociology of action. To simplify this presentation, we will only concentrate on the main ideas in these theories. The 'anthropological' conception is often associated with the name of Leroi-Gourhan (1964) which aims at underlining the close relationship between the human being and the tool: 'technique is considered the continuation of the human being as body and reason', to quote Gras's criticism (1992: 14). As Scardigli also analyses it (1989), this theory leads us to posit that technology is inherently part of the future of humankind. Indeed, by situating technology within an historical perspective, it is considered that its use and its future are inscribed within the womb and that it boasts the ability to create its own destiny. In this way, not only we forget to take into account the social processes at the end of which the actors will temporarily or definitively determine the future of innovation, but we refute them. Based on these findings, the adherents to the Frankfort school have emphasized that the forgotten power struggle in the debates on technology is not an accident. This would result from the will to bury social conflicts which are, however, legitimate, in the name of rationalization inherent in the natural evolution of humanity. Science and technology appear therefore to be essentially ideological (Habermas, 1968) and their link with sport, which according to J.M. Brohm would fill the same functions (Brohm, 1983, 1992), would serve the ambitions of those whose chief interest is to amass profit. 'This perspective boils down to considering the outbidding tactics on the sport equipment as a tangible sign of a power fight where the rich win through' (Duret and Trabal, 2001: 160). In these conditions 'when the will to perpetually transcend leads to instrumentalizing the body itself, "the domination of man over man" means not only totalitarianism founded on the mastery of nature (Marcuse, 1964) but on the deprivation of human freedom which leads as 
far as drugs' (Duret and Trabal, 2001: 161). But by only seeing in technological innovation a vector for domination by the dominant class, the believers in this thesis consider just as much that 'you can't stop progress'. However, this widely shared way of thinking (one needs only listen to conversations in the street to hear the expression), nevertheless creates a problem. Jacques Ellul and his followers attack the 'fatality of technological progress' in order to defend the idea that technology must be understood as part of a 'macro-system' (Ellul, 1977) which would need defining. But this theory also presents weaknesses. For example, we agree with the criticism of Flichy who notes that the theory is:

so all-encompassing that it makes all specific analysis of technical development sterile. To say that there is no technical choice because the most efficient means is what always wins through is to either ignore the complexity of the process of elaboration of a technique, or to posit a tautological reasoning in which the right technique is always that which takes over.

(Flichy, 1995: 37)

To avoid this error which is frequent in the history of the sciences, sociologists have developed a requirement, known under the name of 'principal of symmetry' (Bloor, 1976). Often, in fact, we are tempted to celebrate rationality when scientific discoveries or inventions are introduced, and to consider as irrational those who opposed them. Different models claim to draw inspiration from this school of thought of the sociology of science, centred on action. The idea is to analyse how innovation is accepted or refused, and to identify the arguments of innovators and their critics. In order to do so, the actual science, the technology in the making, must be studied (e.g. Bijker and Law, 1992; Cohen and Pestre, 1998; Latour, 1987). This approach encourages us to follow the whole group of actors in the unravelling of the controversies, while remaining symmetrical.

Before specifying the method that these analyses suggest, we must take into account the several studies conducted on instrumentalization in sport. This task is not easy as the authors interested in the issue have used very different approaches. Some have called upon economic approaches (Desbordes, 2000; Hillairet, 1999), while others have looked into management theories (Ramanantsoa and Ramanantsoa, 1993). But it is the historical studies that, to our way of thinking, describe in the best way the process of innovation. Defrance (1985), for example, shows perfectly the difficulties encountered by promoters of the pole vault made of fibre glass during the introduction of this innovation. The author analyses the types of resistance which are essentially linked to the modification of the physical movement (change based on the sensations of athletes having notably the impression of 'smashing to the ground' while in fact they are going up) and to performance recognition. The latter implies the very meaning the actors give to the sporting competition and their conceptions of the sport. The work of Vigarello $(1988,1999)$, who is interested in describing the evolution of several technologies in the course of the history of sport, clearly demonstrates that the presence of multiple factors explains the evolutions of techniques and instruments, including the representations of sport and of sporting competitions (he reminds us particularly that the introduction of the derailleur gear-shift in the Tour de France cycle race took place 40 years after its invention due to $\mathrm{H}$. Desgranges, Director of the competition, considering this invention to be help in a dishonest and unfair form (1999)), and the tensions between inventors and athletes. 


\section{Methodology}

The 'social resistance' mentioned by the Federation management could therefore have several causes. In the first place, they could be linked to the agents' social position, which according to Lapierre's theses, would well explain the difference between wild water and flat water racing. Second, our understanding of the sociology of technology beckons us to stand back from the idea that "progress goes without saying', a belief which could lead us to make judgements without any chance of understanding this 'resistance'. Moreover, this term is a reminder in itself of the idea of a race for progress, specifically curbed by certain actors. But, as we said before in describing works concerning sociology of innovation, we prefer to stay symmetrical. The new kayak is not to be considered a symbol of progress based on rational thinking transcending the present state and pushing back the limits (here of speed). Nor are those critical of this project to be considered as the 'opposition'. It seems necessary to watch carefully the innovator's speeches by examining very precisely the pros and the cons, the representations and the meanings that protagonists give to sports practice, coaching and performances. Under these conditions, our study takes on three parts: a survey based on a questionnaire, a series of interviews and field observations.

First, we prepared a questionnaire which was then distributed to all top athletes. Then, in order to record the attitudes of coaches, we conducted a series of interviews with 13 people (10 coaches and three members of the technical staff). Finally, we went out several times to the training sites (in particular, that where the prototype was) to talk informally with athletes and trainers using it.

The questionnaire was designed to be filled in by the athletes themselves rather than be carried out by an interviewer. It consists of 36 questions divided into five parts. The first part which is quite routine requests information first of all on several discriminant variables which will allow us to divide up the answers according to criteria such as sex, age social-professional category, geographic location, discipline (flat water racing, slalom, descent), and, second, information on their conception of the sport. The second section aims at recording the equipment used, attitudes towards its strengths and weaknesses as expressed by the athletes, as well as their opinion on the pertinence and use of research into performance. Certain questions will allow us to pinpoint the potential personal investment of athletes in an innovative project; other questions are concerned with their conception of policy and science in sport. The third part is intended to identify athletes' attitudes to technology. Starting with concrete questions on their routine, it is then possible to explain their use of technology. Several questions are about computing. Studies (e.g. Trabal, 1996) have shown that the computer is the object of much fear and criticism (the machine is often dubbed 'inescapable' and demands that everyone 'keeps up' despite 'delays'). The purpose of the questionnaire's fourth part is to group together information on the school history of the athlete. We can assume, following the reading of theses of the Bourdieu school, that the social link to knowledge (Charlot, 1982, 1991) plays a decisive role in scholastic capital, which is part of the social position (Bourdieu and Passeron, 1970). Finally, the fifth and last section attempts to identify attitudes to science and rationality which could come into play in the social 
contact with technological innovation (Trabal, 1997). The questionnaire was distributed and completed in the first semester of 1998 through the go-between of coaches of 177 top athletes registered on the lists of the Federation. The rate of return was 48.9 percent. As Table 1 indicates, it is particularly the younger generation (highly motivated by their recent registration on the list of topathletes, synonymous with their new social identity) who responded.

The interviews, carried out between October 1998 and October 2000, were with 13 people including 10 national coaches (six people working in flat water racing and four in wild water), with two technical staff members and with the innovator (former member of the management team). Their duration is between 40 minutes and one hour 15 minutes. They were quite free in form and were completed with a table to note down the subjects' training, the conditions in which they carried out their profession, their relationship with colleagues of other disciplines, their relationship with researchers into sport science, and their comments on the equipment, particularly their opinions on the new boat. These interviews were recorded then transcribed in full. They were processed with the software programme Prospéro ${ }^{\odot}$. This software, developed by F. Chateauraynaud and J.P. Charriau, is intended to help researchers in their work on texts in natural language ${ }^{1}$ built for the sociology of controversies, this programme fits to our corpus well.

Finally, we undertook observation on several training sites. We were particularly attentive (nine visits) to the site which played host to the boat on its departure from the constructor (1998). At these times, we were able to talk informally with athletes who shared with us their reactions to the prototype, and with coaches who were giving the athletes advice.

\section{Results}

\subsection{The Quantitative Study}

The discriminant variables inform us of some characteristics of the population which responded to our questionnaire. In addition to the information presented in Table 1, it is to be noted that females responded a lot less than males $(33.3 \%$ compared to $54.1 \%$, respectively) and that their age (in 1998, when the survey was carried out) varies between 16 years and 34 years (the average is 22.8 years, with a difference of 3.52). Some 59 people out of the 87 who responded declare to be studying. In a little more than one half of the cases, training is being pursued to become a teacher in physical and sports education, or to become a coach. Thirty athletes have a professional activity. With one exception (a labourer), they can be divided up into almost three equal groups of executives, intermediate professions and employees. Only half have a professional activity directly related to the sporting professions. When one looks closely at the socio-professional categories of their parents, we remark that they originate from three SPC: out of 87 responses, 29 have a father who is an executive, 22 a father who has an intermediate profession, and 13 are children of employees. However, these categories cannot be equated with the practised discipline (flat water racing, slalom, descent). We are 
Table I Rate of Return

\begin{tabular}{|c|c|c|c|c|c|c|c|c|c|c|c|c|}
\hline & $\begin{array}{l}\text { Line racing } \\
\text { Number of } \\
\text { athletes }\end{array}$ & $\begin{array}{l}\text { Number of } \\
\text { responses }\end{array}$ & $\begin{array}{l}\% \text { of } \\
\text { response }\end{array}$ & $\begin{array}{l}\text { Descent } \\
\text { Number of } \\
\text { athletes }\end{array}$ & $\begin{array}{l}\text { Number of } \\
\text { responses }\end{array}$ & $\begin{array}{l}\% \text { of } \\
\text { response }\end{array}$ & $\begin{array}{l}\text { Slalom } \\
\text { Number of } \\
\text { athletes }\end{array}$ & $\begin{array}{l}\text { Number of } \\
\text { responses }\end{array}$ & $\begin{array}{l}\% \text { of } \\
\text { response }\end{array}$ & $\begin{array}{l}\text { Total } \\
\text { Total } \\
\text { Number }\end{array}$ & $\begin{array}{l}\text { Number of } \\
\text { responses }\end{array}$ & $\begin{array}{l}\% \text { of } \\
\text { responses }\end{array}$ \\
\hline Elite & 10 & 4 & $40.0 \%$ & 10 & 4 & $40.0 \%$ & 8 & 6 & $75.0 \%$ & 28 & 14 & $50.0 \%$ \\
\hline Senior & 22 & 8 & $36.4 \%$ & 9 & 9 & $100.0 \%$ & 17 & 7 & $41.2 \%$ & 48 & 24 & $50.0 \%$ \\
\hline Youth & 18 & 17 & $94.4 \%$ & 15 & 9 & $60.0 \%$ & 21 & 13 & $61.9 \%$ & 54 & 39 & $72.2 \%$ \\
\hline Hope & - & - & - & 31 & 3 & $9.7 \%$ & 16 & 3 & $18.8 \%$ & 47 & 6 & $12.7 \%$ \\
\hline S.R. & & & - & - & 2 & - & - & 2 & - & - & 4 & - \\
\hline Total & 50 & 29 & $58.0 \%$ & 65 & 27 & $41.5 \%$ & 62 & 31 & $50.0 \%$ & 177 & 87 & $48.9 \%$ \\
\hline
\end{tabular}

Table 2 Do You Spend Much Time on the Outfitting (Answers According to the Speciality)?

\begin{tabular}{|c|c|c|c|c|}
\hline \multirow[b]{2}{*}{ Personal time spent on outfitting } & \multicolumn{4}{|l|}{ Speciality } \\
\hline & Line racing & Slalom & Descent & Total \\
\hline Yes, I work on it continuously & 2 & 0 & 1 & 3 \\
\hline $\begin{array}{l}\text { Yes, as soon as I feel that better } \\
\text { adjustment is possible }\end{array}$ & 14 & 16 & 9 & 39 \\
\hline No, unless there is an obvious problem & 10 & 14 & 14 & 38 \\
\hline No, I never touch it & 2 & 0 & 1 & 3 \\
\hline Total & 28 & 30 & 25 & 83 \\
\hline
\end{tabular}


very close to a state of independence, and if we wanted nevertheless to examine the connection, we would have to say that it is essentially due to the modest background of the parents of athletes of descent. It can no longer be affirmed, as was perhaps the case in the 1980s, that flat water recruits its athletes from the most underprivileged sections of the population.

When analysing the responses to questions about what athletes particularly like in sport and in their discipline, we first of all notice, among the reasons most often chosen, 'a way to extend oneself', 'for pleasure' before that of 'winning'. As far as sporting values are concerned, they are by far the least mentioned. Second, when addressing and coding ad hoc the answers to an open question, we are struck by the fact that the comments vary according to the speciality: dealing with natural elements is more often referred to by descenders $(51.9 \%$ compared to $41.9 \%$ and $34.5 \%$ for slalom and flat water racers respectively). Slalom racers stand out especially for mentioning the atmosphere (29\% compared to $10.3 \%$ for the 'flatties' and $3.7 \%$ for the descenders). As far as athletes of flat water racing are concerned, they refer to the competition (34.5\%) while this is hardly mentioned by wild water racers $(6.5 \%$ of slalom racers and not one descender); likewise, more 'flatties' invoke pushing themselves to the limit $(27.6 \%)$ while the respective percentages of slalom racers and descenders are 6.5 percent and 18.5 percent. In this way, the opposition flat/wild water racing is not emphasized by social background (SPC of parents) but is underlined by the comments describing the disciplines.

Among questions on equipment, the attitude to outfitting deserves close attention. Indeed, we can admit that an athlete who spends much time on the outfitting considers that the equipment plays a significant role in performance (Table 2).

We notice that the two extreme choices ('work on it continuously' and 'never touch it'), have rarely been chosen. Therefore, it seems pertinent to gather together the 'yes' answers to better distinguish them from the 'no' answers, in order to evaluate the difference in independence. We note however that the link between these two variables is almost non-existent $\left(\chi^{2}=1.7\right.$, ddl $\left.=2, p=0.429\right)$. Once again, the idea that athletes of wild water spend an enormous amount of time checking their equipment, while the 'flatties' are happy to 'row' without a worry about outfitting proves unfounded.

Another means to understanding the relationship between athletes and their equipment is to pay particular attention to their judgement on the issue. Only 11 of them declare they are dissatisfied with their equipment. Among the others, we can only count six negative answers. This tends to indicate their interest in these questions. Out of the 145 answers, what appears to be appreciated most is essentially rigidity (24 answers), holders and paddles (18), aesthetics (16), lightness and reliability (10 for each), performance (nine), strength (eight). The liveliness of the boat and the quality of the construction each only receive seven positive answers.

We then suggested different statements (formulated after our informal discussions during our field work) which the athletes were asked to number according to a degree of agreement ( 0 indicating disagreement, 10 agreement). It is then possible to calculate an average, for each group, and therefore to compare them. 


\section{Table 3 Averages According to the Speciality for Each Item of the Question 22}

\begin{tabular}{llll}
\hline & $\begin{array}{l}\text { Line racing } \\
(n=29)\end{array}$ & $\begin{array}{l}\text { Slalom } \\
(n=31)\end{array}$ & $\begin{array}{l}\text { Descent } \\
(n=27)\end{array}$ \\
\hline The best boat . . is the current world champion's boat & 3.96 & 2.93 & 2.59 \\
The best boat . . is mine! & 4.86 & 6.12 & 6.31 \\
The best boat is the one I will have built in & 5.37 & 6.61 & 5.11 \\
$\begin{array}{l}\text { collaboration with a constructor } \\
\text { The best boat is the one studied in the laboratory }\end{array}$ & 4.30 & 2.97 & 4.00 \\
$\begin{array}{l}\text { The best boat is the one my coach will recommend } \\
\text { I am not very informed of the latest technological }\end{array}$ & 4.19 & 3.47 & 4.3 \\
$\begin{array}{l}\text { developments in boat building } \\
\text { There is no such thing as the right boat, it is the }\end{array}$ & 6.22 & 3.29 & 3.37 \\
right athlete that counts & & 6.90 & 5.58 \\
All competitors should have the same boat & 3.61 & 0.77 & 2.80 \\
\hline
\end{tabular}

Table 3 points to several differences between wild water and flat water racers. The latter have faith more often in the prestige of a boat which has proved its worth, in the field or in the laboratory, and tend to believe a little more than the others in the myth of the sporting competition safeguarding equality even if it should not be forgotten that they generally refuse uniformity of the equipment (the average is only 3.6/10). The slalom racers are more tempted than their colleagues to construct a new boat while at the same time conceding more easily that it is not the boat that determines the performance (and even less the engineers in the laboratories). It is the descenders who place the most importance on the equipment (or on themselves). But beyond the discriminant characteristics distinguishing the different populations, it is necessary to listen to the athletes' comments. Overall, they refuse to believe in a miracle boat (it is not that of the world champion, nor the result of work by researchers working in a laboratory) and do not have faith in their coach on this point. The right boat is not inaccessible: if it is not their own, they hope to build it. In any case, they consider themselves at the centre of the performance (second-last item) and stay up-to-date on the latest technological developments. One question gave an insight into their indecision to change boats (Table 4).

Once again, most athletes, whatever the discipline, seem to be ready for change. Of course, these are only words. However, very few militant attitudes refusing innovation are to be noted. All things considered, athletes in flat water racing do not appear to be opposed more than the others to adopting new technologies.

Similarly, questions seeking athletes' opinions on research into sports science lead us to believe that athletes of every discipline are more or less interested in this approach. Fifty-two people declare themselves ready to contribute without restriction to new research, while four would accept under certain conditions. The others refuse basically due to a lack of time. Therefore, the athletes declare in the majority to be interested in the development of research, and satis- 
Table 4 Responses to the Question 23 (Numbers and Funding) According to the Speciality

\begin{tabular}{|c|c|c|c|c|}
\hline \multirow{2}{*}{$\begin{array}{l}\text { If you are offered a new boat, would } \\
\text { you want to use it for your next } \\
\text { competition? }\end{array}$} & \multicolumn{4}{|l|}{ Speciality } \\
\hline & Line racing & Slalom & Descent & Total \\
\hline Yes, without hesitation & 4 & 1 & 2 & 7 \\
\hline No & 2 & 2 & 1 & 5 \\
\hline Yes, if I have the time to get used to it & 22 & 28 & 23 & 73 \\
\hline Total & 28 & 31 & 26 & 85 \\
\hline Number of months necessary to get used to it & 2.04 & 2.56 & 2.91 & 2.51 \\
\hline $\begin{array}{l}\text { No. of subjects taken into account in the } \\
\text { calculation of this average }\end{array}$ & $(n=21)$ & $(n=28)$ & $(n=23)$ & $(n=72)$ \\
\hline
\end{tabular}

fied with their equipment even if they consider that things could be pushed even further in the quest for a better performance. In relation to this last point, we asked them if they thought the Federation should participate in the fine-tuning of new equipment. Forty-nine agreed while 31 were against the idea. Among comments justifying why the Federation should work in this direction, we count 33 percent of athletes who declare that 'this is their role', 29 percent emphasize the need to carry out research, 19 percent refer to the quest for the best performance, while 12 percent are of the opinion that in this way, problems of monopoly and/or additional costs are avoided. Those who consider that the Federation should not work in this direction (seven flat water racers, 14 slalom racers and 10 descenders) are most often of the opinion that research into new equipment should be done individually (eight people, that is $15 \%$ ), or that this is not the function of the Federation (13\%), or that it is up to the constructors to do so (10\%). Overall, we can say that the athletes would be prepared to commit themselves alongside the Federation to research into improvement of equipment; the K1 project therefore seems able to claim followers.

The answers to questions about athletes' attitudes to technology cannot be explained with reference to their specialities: most are open to new technology, especially to computing. Those who do not have a computer and those who do not have access to the Web generally wish it were possible; only 11 percent of responses marked an outright refusal to having a computer.

Their relationship towards schooling is mostly positive. Generally, our athletes like school, especially those who practise flat water racing (65.5\% compared to $51.9 \%$ and $49.1 \%$ for the descenders and slalom racers respectively). Effort at school is, however, varying. Overall, it can be said that half the population declare to have worked hard while the other half admit to the contrary. As for results, these are generally considered to have been satisfactory; only 11 athletes (four flat water racers, four slalom racers and three descenders) claim to have met with difficulties. The issue of theoretical training becomes particularly pertinent when that of the boats in question is considered. A digital variable, rating from 0 to 10 (as for the previous question) athletes' degree of agreement on statements allows for comparisons between the means of the different groups (Table 5). 


\section{Table 5 Averages of Responses Given According to Specialities (0 Indicates Disagreement, 10 Total Agreement)}

\begin{tabular}{llll}
\hline $\begin{array}{l}\text { A demonstration of the study of } \\
\text { shapes of canoes and kayaks }\end{array}$ & $\begin{array}{l}\text { Line racing } \\
(n=29)\end{array}$ & $\begin{array}{l}\text { Slalom } \\
(n=31)\end{array}$ & $\begin{array}{l}\text { Descent } \\
(n=27)\end{array}$ \\
\hline$\ldots$ is always interesting & 8.52 & 8.38 & 7.88 \\
$\ldots$. is generally difficult for me to understand & 4.07 & 2.48 & 3.88 \\
$\ldots$. is very useful & 7.38 & 6.72 & 6.54 \\
$\ldots$. is extremely boring & 2.78 & 2.31 & 3.73 \\
I would like to undergo training in order to & 4.96 & 5.48 & 5.08 \\
better understand & & & \\
\hline
\end{tabular}

Table 5 indicates, once again, that the athletes are on the whole interested in theoretical demonstrations about equipment. The majority refuse to consider them repetitive and on the contrary recognize the utility of such an approach, whatever the speciality. Differences introduced by this variable underline a higher level of interest by the flat water racers even if they seem to have more problems in understanding (previous questions indicated that this population is the weakest in physics while wild water racers had known difficulties in the humanities).

The final questions were about science. Generally, the athletes hold in high opinion scientific research and consider it to be of use. While of the belief that scientific efforts are not the only means to accessing the truth, overall the athletes rejected knowledge which was not founded on rationality.

\subsection{Qualitative Study}

Let us begin by considering the comments made about the boat. At one stage or another, we asked the inevitable question: 'if you met with the opportunity of using it (coach of flat water racing, with an athlete likely to use it), would you try it out?' The answers are generally positive: 'We've already asked several times', 'of course!' or even 'the boat is good'. However, some were not informed; others confused it with a project for a new 'leisure' boat. This lack of information is often denounced. But the real question seems to be that which surrounds the use of the boat by the athletes.

Researcher: To come back to the latest $\mathrm{KI}$, if it was suggested that you use it here on this site, would you agree or not?

Coach I: Well, yes! If we are told: OK, you've got this boat to test, here's the construction protocol, here's the means to do it, and here are two or three extras, well yes!

Researcher: And you think that the athletes would agree?

Coach I: Yes, but, well ... in the end ...

Coach 2: They have to realize that it's an opportunity!

Coach I: But how are we going to sell it to them? What is clear is that it should have been sold to us before. But even if it's been sold to us, we will need the means to be able to sell it to others. 
This extract highlights two important areas. In the first place, it 'should have been' sold to the coaches beforehand. The deontic modal verb ('should have been') is particularly interesting as it of course pinpoints an error committed beforehand, but the present tense everywhere else in the same utterance makes clear that the idea that 'it is too late' is reversible. Second, the boat is not referred to with respect to its technical features or its advantages in competition, but appears as a 'product' in the commercial sense of the word, as there is clearly the issue of being 'able to sell it'. This initial analysis compels us therefore to consider that the $\mathrm{K} 1$ boasts real advantages in the eyes of the coaches (otherwise they would not agree to use it, or even try it). It could be said that this boat summons up a reaction in the form of 'yes, but ...'.

The 'but' clause generally corresponds to criticism of the Federation. If it is fairly well recognized that it is the Federation's role to launch into the conception and making of new equipment, the degree of priority to be placed on this mission still needs defining. And here is where opinions diverge. For some, it is essential: 'the moment we stop doing that, we'll have to take a serious look at our legitimacy ...' (Coach 4). Others judge it less important: 'If the Federation is able to manage that side of things, well that's all well and good! But at the same time it should not be a priority for the Federation' (Coach 3). In fact, generally, those who consider this mission as less of a priority call attention to other urgent concerns. The federal method is often the object of criticism, since the decision to go ahead in this adventure was not subject to a vote, nor even to negotiation. In fact, the conception and elaboration of the $\mathrm{K} 1$ seems to have resulted out of the conjunction between an idea, a technical and financial possibility and political involvement. What is disapproved of is that the project was decided upon without consultation or involvement of the actors, those precisely whose vocation it is to test and use the new boat. Others believe that it would have been necessary to 'sell them' the boat (Coach 1). A final coach interviewed considers that the right method would not be to talk about it with the coaches, but to 'involve the athletes in the project, to get them interested, and that they then become the spokespersons for the equipment' (Coach 5). We can speculate that this final method would have provoked just as much bitter feeling. In a more general way, the fact that the project is not "carried federally and by a whole group of executives' (Coach 4) is a problem. The open hostility towards this project expressed by a technical staff member combines mixed feelings such as 'I think that I would like it to really work one hundred percent; it's just that at each stage of the project, you really need complete support and great interest in the thing' (Coach 5).

The dissension surrounding the venture can be explained by the different types of evidence upon which judgements are based. Some will focus on readings obtained in the sea plane tank. The advantages and the pertinence of a point of the curve will be discussed. The boat sparks interest once it reaches a particular speed. Is this speed systematically reached in international competitions? In the case of head wind, does this boat always have the edge? Such are the many considerations sparked by the obtained curve. Others, on the other hand, attack this means of resolving the debate. It is not so much the metrology which is criticized as the interpretation it generates: races do not take place in a sea plane tank. Another way to infer the limits of the tests conducted in the pond is to emphasize 
the performances during a race. 'We need results' is certainly a constraint and a shared objective. But for some, medals, or even certificates of merit, seem to be pertinent elements by which to judge the material. These elements make up a metrology, competing with the readings (also measured) obtained in the pond. Other comments on the boat are based on the technical difficulties of getting used to it. Spontaneously, athletes want to sit towards the front of the boat to feel familiar and 'at home' in it, otherwise headway would not be made. After a number of tests, coaches and athletes have been able to obey the instructions given by the innovator which suggest sitting closer to the back. Of course, at lower speeds, efforts are rewarded with difficulty. But many admit that at 100 percent exertion, improvement in stability is perceptible.

It is interesting to note that these different areas of evidence may be summoned simultaneously. Scientific justifications based on curves and readings, a metrology spanning over the number of medals, sensations of the athletes in the grips of dealing with the boat, cannot separately suffice. Belief or non-belief in the project is a matter of adjusting to all these arguments. 'It needs to be sold' said the coach. Just like a sales representative in the throes of trying to convince his client must mobilize all the resources at his disposal (a 'product brochure' containing the measurements, understanding of the psychology of the person opposite, subjective descriptions of its uses, etc.), it is through a range of approaches that the conviction can be fostered. Through attention to the markers within the language - provided by the programme Prospéro - it is plain that all the actors are basing their judgement of this boat on disparate elements.

These interviews also alert our attention to the nature of the opposition between coaches of flat water and wild water racing. Let us examine a significant passage:

For example, when it comes to quite a few of the best athletes in flat water racing, these are people who have suddenly changed. So they have a sort of double culture and I think that the mentality is changing and that things are on the move.

In what way?

In the way that it's less violent, less aggressive and as well, we might say, more like a consensus, that is to say there's more work in common, less of a hierarchy, less of the permanent conflict between coaches and athletes, things like that. The open warfare a few years ago was public knowledge, warfare between the athletes and the coaches, war between wild water and flat water racing, war between the representatives of flat water and the representatives of wild water at the Federation. That's what it was, and I don't mind it at all if my comments are noted down, I think that things are moving in the right direction. And that the Federation is trying to do something which is more unifying. (Coach 5)

Moreover, words like 'war', 'violent', 'aggressive', etc. (picked up by the software), mark the nature of the tensions which, even if they belong to the past, remain present in memory. The willingness to transcend these former arguments does not mean they are forgotten. We were reminded of cases considered 'typical' or 'important' by almost everyone. It is therefore interesting to note in what conditions these memories have been sparked, just as, of course, the study of the current state of resistance necessarily involves analysing the grounds upon which the actors made mention of these tensions. Outside controversy about training 
methods and cultural differences, the actors show disagreement on questions concerning unequal distribution of the resources (budget, number of coaches, grants for the infrastructure, more symbolic investments). First, the flat water racers insist on their lack of coaches, on 'disgraceful cloakrooms, disgraceful showers', on not one 'possibility of having a workroom for the athletes in which to study in between training sessions'. Second, the effort of investment in research on this boat can be registered. But we come back to the conditions of the launching of this project: spurred on by an innovator from the field of wild water and a former technical staff member in charge of flat water racing who is, in this way, associated with the previous disputes, the making of the boat was not decided on collectively with representatives from line racing. Therefore, the value of this contribution loses weight and the question of priorities returns to the fore.

The political angle therefore becomes central. It is dependant on the question of power, sometimes condemned - as we have seen - because of the contrast wild/flat water racing, to which can be added the opposition between the capital and the countryside. We could simplify this image with, on one side, the flat water racers, who are few in number, live in rural areas, far from everything and in particular the decision- and strategy-making, concentrating on endurance work, and, on the other side, the wild waters, in particular the slalom racers, who for the most part work in Paris, far from the reality of the field, defining policy, activating networks, building up communication, making decisions without making contact with the field.

Paris is like an ants' nest. There's only one guy who's interested in line racing there . . As for all the others, it's just to show off, the slalom racers with their concepts, their jargon, but it's high time that the feds invested in what is at the grass roots of our existence: sport! They have to recognize those who work hard in the field, in other words those who are getting people involved in the sport. To achieve performance, that takes time (. .) In this day and age, wild waters, is all about sitting on backsides and pushing paper! (Coach I)

The new boat, a project supported by 'the people of wild waters', symbolizes the project decided on 'in the capital' without prior consultation of people in the field. Moreover, the boat remains on the site closest to the capital. Other coaches shared with us a whole batch of anecdotes, challenging the strategy of so-and-so or so-and-so (whatever the discipline), the injustice of the selection process, the incompetence of certain actors, etc.

This body of discourse brings to the fore the fact that the Federation is the object of very harsh criticism. This formula brings to mind traditional questions for the sociologist of work: who is targeted by the term federation? Is it the management? We have seen that the technical management is targeted, but just as much as are former managers, the role of the capital, and the history of the institution.

\section{Discussion}

The quantitative study globally invalidates the hypothesis that athletes of line racing be very different from their colleagues. The social differences identified 
by Lapierre, which seemed legitimate to take into account, considering the comments made by different technical staff members, does not appear plausible. At least as far as the top athletes who answered our questionnaire are concerned, it cannot be said that the social background of the 'flatties' is underprivileged compared to that of their colleagues. Neither can it be said that they are less interested in the technical aspects of their boat, more sceptical towards the work of scientific researchers into sport, or less motivated by new technology. If anything, they have a little difficulty in physics while their colleagues have problems in other subjects, but the flat water racers are among the most interested in theoretical explanations on the shapes of their boats.

As for the qualitative study, we have been forced to discuss sociologies of innovation and to move on from our initial problem. A quick reading could nurture the theses of the Frankfort school in emphasizing the link of domination: managers in the Federation would impose technological innovation (i.e. the new kayak) and their conception of the world - Sport's Performance - in a same movement. But the links between these two dimensions are more complex. 'Flatties' proved to be able to criticize the Power on the one hand, and to ask some evidence of the efficiency of the boat on the other hand. In order to analyse the relation between these two fields, our work now urges us to go beyond the sociological debate on technological innovation (as we presented it in our second part), since it seems important to articulate the issues of work organization, the criticism of the use of Power, the strategies in place, while keeping in mind the history of the institution.

This study encourages us to abandon those sociological models which demand prior operations of qualification. In the first place, the difference in social positions of the actors of line and wild water racing, if ever it was pertinent 20 years ago, offers little contrast today, and in any case cannot help explain the connection to innovation. When sociologists base their analyses on qualifications, they focus on a situation while forgetting it is capable of evolving. However, actors change; while history is there to stay (we have seen the influence of memories of the past on the actors), sociological analysis must be able to explain this change. Second, the term 'resistance to innovation' is also a problem. The essence of resistance is to hide one's action and to force the others to call themselves the opposition. The need for evidence is therefore reversed as it weighs heavily, not on the opposition, but on those accusing them of resistance. Moreover, as the actors hardly allow themselves to be shut into timeless qualifications, they play on the limits and on the criteria upon which these qualifications are based. The sociologist must avoid becoming the instrument of such qualification but must study the accusations of resistance and its consequences.

This study places in an unenviable position sociology which feels that study needs to be dependent on classifying and qualifying the social actors. It also points to the limits of the sociologies of innovation which attempt to reduce their material to the unique element of innovation. In fact, the controversy surrounding the boat goes well beyond a dispute confined to the scientific arena that would be centred on the evidence and legitimate arguments given by all members of the community. Quite the opposite, if we take the discussion about a point of inflexion of a lower curve with a quarrel about the status of the innovator, we have a 
debate concerned just as much with the sea plane tank as with the priority given to the validation of the prototype as opposed to the state of the showers and cloakrooms. Sociology cannot therefore continue to be divided up into different specialities if we do not work on the way we can move from sports sociology to technical sociology, from sociology of innovation to that of the workplace, from political sociology to that of morals.

Maybe, the reversal proposed by the Pragmatics, in so far as C.S. Peirce or W. James tried to show how many practical questions are deciding factors in actions and conceptions, is a solution. The idea is to study the dynamics of the qualifications (and not to distinguish social practices with variables built by the sociologist), the authentication process used by the actors to agree (or not) on action principles. In considering our object as a professional controversy, we may study simultaneously the stormy history of innovation attempts (with old memories being brought back) and the dynamism of the actors' evolution (e.g. when one changes his way of thinking). After the work of Chateauraynaud (1991) about professional misconduct, we can consider all theses debates as an affair the outcome of which we cannot predict. ${ }^{2}$ So, it seems possible to explain the weight of the past and the gates to the future. The questions of priority and urgency alluded to by the flat water racing coaches, the importance given by the athletes to the time needed to get used to the new boat, the memory of former disputes which the actors have trouble forgetting, all underline a time dimension described in particular by philosophers (Duval, 1990).

To explain this, we would need to develop all the concepts, but particularly continue this research by working on the history of the boat as it is connected to the history of the institution. The study presented here essentially opens a new axe of thought encouraging simultaneous work into history, technology, the political dimension, and into the nature of the sporting competition.

\section{Notes}

1. See [www.prosperologie.org] and Chateauraynaud (2003).

2. For example, the good sports results after the end of this empirical study - with the classical boat - may mortgage the new boat's future.

\section{References}

Bijker, A.E. and Law, L. (eds) (1992) Shaping Technology Building Society. Cambridge, MA: MIT Press.

Bloor, D. (1976) Knowledge and Social Imagery. Chicago, IL: University of Chicago Press, 1991. Bourdieu, P. and Passeron, J.C. (1970) La reproduction. Paris: Minuit.

Brohm, J.M. (1983) 'Le sport: une institution de classe bourgeoise', Quel corps? 21/22: 61-4.

Brohm, J.M. (1992) Les meutes sportives. Paris: L'Harmattan.

Charlot, B. (1982) 'Je serai ouvrier comme papa, alors à quoi ça me sert d'apprendre?, Échec scolaire, démarche pédagogique et rapport social au savoir', in GFEN collectif, Quelles pratiques pour une autre école? Paris: Casterman.

Charlot, B. (1991) 'L'échec scolaire en mathématiques et le rapport social au savoir', in R. Bkouche et al. (eds) Faire des mathématiques: le plaisir des sens. Paris: Armand Colin. 
Chateauraynaud, F. (1991) La faute professionnelle- une sociologie des conflits de responsabilité. Paris: Métailié.

Chateauraynaud, F. (2003) Prospero: une technologie littéraire pour les sciences humaines. Paris: Editions du CNRS.

Cohen, Y. and Pestre, D. (1998) 'Presentation', Annales Histoires, Sciences Sociales 4/5: 721-44.

Defrance, J. (1985) 'L'adoption de la perche en fibre de verre', Culture Technique 13: 257-64.

Defrance, J. (1995) Sociologie du sport. Paris: La Découverte.

Desbordes, M. (2000) Gestion du sport. Paris: Vigot.

Duret, P. and Trabal, P. (2001) Le sport et ses affaires - une sociologie de la justice de l'épreuve sportive. Paris: Métailié.

Duval, R. (1990) Temps et vigilance. Paris: Vrin.

Ellul, J. (1977) Le système technicien. Paris: Calmann-Lévy.

Flichy, P. (1995) L’innovation technique. Paris: La découverte.

Gras, A. (1992) 'Le bonheur, produit surgelé', in A. Gras and C. Moricot (eds) Technologies du quotidien. Paris: Editions autrement.

Guttmann, A. (1978) From Ritual to Record: The Nature of Modern Sports. New York: Columbia.

Habermas, J. (1968) Technik und wissenschaft als ideologie. Frankfurt am Main: Suhrkamp.

Hillairet, D. (1999) L'innovation sportive - Entreprendre pour gagner. Paris: L'Harmattan.

Lapierre, A. (1981) 'Sports de pleine nature et pratiques sociales. Analyse socioculturelle du canoekayak et de l'escalade', Mémoire INSEP, Paris.

Latour B. (1987) Science in Action - How to Follow Scientists and Engineers through Society. Cambridge, MA: Harvard University Press.

Leroi-Gourhan, A. (1964) Le geste et la parole I. Technique et langage. Paris: Albin Michel.

Marcuse, H. (1964) One-dimensional Man - Studies in the Ideology of Advanced Industrial Society. Boston, MA: Beacon Press.

Pociello, C. (1983) Le rugby ou la guerre des styles. Paris: Métailié.

Pociello, C. (1999) Sport et Sciences Sociales. Paris: Vigot.

Pociello, C. et al. (eds) (1981) Sports et Société. Approche socioculturelle des pratiques. Paris: Vigot.

Ramanantsoa, M.M. and Ramanantsoa, B. (1993) 'Les fedérations sportives au risque des nouvelles technologies', in A. Loret (ed.) Sport et Management, pp. 149-58. Paris: Bordas.

Scardigli, V. (1989) 'Nouvelles technologies: l'imaginaire du progrès', in A. Legras et al. (eds) L'imaginaire des techniques de pointe - au doigt et à l'oeil, pp. 97-114. Paris: L'Harmattan.

Trabal, P. (1996) 'Au sein de l'établissement scolaire, des réticences à l'ordinateur', La revue de l'EPI 81: 71-80.

Trabal, P. (1997) La violence de l'enseignement des mathématiques et des sciences - une nouvelle approche de la sociologie des sciences. Paris: L'Harmattan.

Vigarello, G. (1988) Techniques d'hier et d'aujourd'hui. Paris: Laffont/EPS.

Vigarello, G. (1999) 'Le sport dopé', Esprit 1: 75-91.

Villiger, B. (1996) 'Les écarteurs de narines améliorent-ils les performances du footballeur?'; FIFA Magazine, pp. 44-6.

Patrick Trabal is Professor of Sociology at Paris X-Nanterre University and at the Higher School of Social Sciences (EHESS) in Paris. He is the co-director of the Social Sciences Team in the Sport \& Culture Laboratory and the scientific manager of the Social Sciences \& Doping Centre. His works deal with the sociology of sport, the sociology of risk, pragmatic sociology and the computer analysis of textual data.

Address: University Paris X-Nanterre, Lab. Sport \& Culture, 200 av. de la république, 92000 Nanterre, France. Email: ptrabal@u-paris10.fr 